\title{
Comparison of three tester parents in evaluating popcorn families derived from IAC-125
}

\author{
Comparação de três testadores na avaliação de famílias de milho pipoca derivadas de \\ IAC-125
}

\author{
Acácio Antonio Miotto², Ronald José Barth Pinto ${ }^{3 *}$, Carlos Alberto Scapim³ ${ }^{3}$ José Lidércio Matias Junior ${ }^{4}$, \\ Marlon Mathias Dacal Coan ${ }^{4}$ and Hingrid Ariane da Silva ${ }^{2}$
}

\begin{abstract}
Thirty-eight $S_{3}$ families obtained by selfing from IAC-125 popcorn hybrid were evaluated by three different topcross tester parents: an inbred line $\mathrm{P}_{3.3}-\mathrm{S}_{7}$ generation taken from popcorn population CMS-42, an open-pollinated variety BRS Angela and the commercial three-way hybrid Jade. Manual crossings were performed according to a partial diallel mating design. Topcross hybrids were evaluated in individual experiments for each tester carried out in randomized block designs with three replications in two locations (Maringá-Paraná and Sabáudia-Paraná). The results for grain yield and popping expansion were gathered in a combined analysis. Estimates of general and specific combining ability were obtained according to Griffing's methodology (1956), adapted by Geraldi and Miranda Filho (1988). The hybrid Jade was considered the most appropriate tester because it discriminated the evaluated families well for both grain yield and popping expansion according to Fasoulas index of differentiation. Families $\mathrm{F}_{4}, \mathrm{~F}_{7}, \mathrm{~F}_{16}$ and $\mathrm{F}_{31}$ are the most promising due to their high general combining ability for both traits as well their performance regardless of the effect of locations.
\end{abstract}

Key words: Topcross. Popping expansion. General combining ability.

RESUMO - Trinta e oito famílias $\mathrm{S}_{3}$ obtidas por autofecundação do híbrido de milho pipoca IAC-125 foram avaliadas por três diferentes testadores em cruzamentos topcrosses: a linhagem $\mathrm{P}_{3.3}$ em $\mathrm{S}_{7}$ obtida da população de milho pipoca CMS-42, BRS Angela que é uma variedade de polinização aberta e o híbrido triplo comercial Jade. Cruzamentos manuais foram realizados conforme o esquema de cruzamentos de um dialelo parcial. Os híbridos topcrosses foram avaliados em experimentos individuais para cada testador, no delineamento de blocos casualizados com três repetições, em dois locais (Maringá e Sabáudia). Os resultados obtidos para a produtividade de grãos e capacidade de expansão foram reunidos em uma análise conjunta para locais. As estimativas de capacidade geral e específica de combinação foram realizadas de acordo com a metodologia proposta por Griffing (1956), adaptada por Geraldi e Miranda Filho (1988). O híbrido Jade foi considerado o testador mais adequado porque discriminou melhor as famílias avaliadas de acordo com o índice Fasoulas de diferenciação, tanto para a produtividade de grãos quanto para capacidade de expansão. As famílias $\mathrm{F}_{4}, \mathrm{~F}_{7}, \mathrm{~F}_{16}$ e $\mathrm{F}_{31}$ se mostraram como as mais promissoras devido à alta capacidade geral de combinação para as duas características, independentemente do local avaliado.

Palavras-chave: Topcross. Capacidade de expansão. Capacidade geral de combinação.

\footnotetext{
*Autor para correspondência

DOI: $10.5935 / 1806-6690.20160068$

'Recebido para publicação em 15/03/2015; aprovado em 23/11/2015

Parte da Dissertação de Mestrado do primeiro autor apresentada ao Programa de Pós-Graduação em Agronomia, Universidade Estadual de Maringá/UEM

22Programa de Pós-Graduação em Agronomia, Universidade Estadual de Maringá/UEM, Maringá-PR, Brasil, acaciomiotto@gmail.com; hingrid_ariane@ hotmail.com

${ }^{3}$ Departamento de Agronomia, Universidade Estadual de Maringá/UEM, Avenida Colombo, 5790, Bloco, J45, $1^{\circ}$ Piso, Zona 7, Maringá-PR, Brasil, 87.020-900, rjbpinto@uem.br; cascapim@uem.br

${ }^{4}$ Programa de Pós-Graduação em Genética e Melhoramento, Universidade Estadual de Maringá/UEM, Maringá-PR, Brasil, jose.lidercio@ limagrain.com, marloncoan@gmail.com
} 


\section{INTRODUCTION}

Developing and evaluating inbred lines are the most expensive and laborious steps of hybrid maize production (PINNISCH et al., 2012). Given the impossibility of working with all hybrid combinations from a large number of parents, (CRUZ et al., 2012), the use of topcrosses has become an important option to easily and quickly evaluate inbred lines.

Jenkins (1935) and Sprague (1946) suggested early generation testing in inbred lines to accelerate the development of lines. This methodology has been designed with the aim to eliminate lines that do not have considerable merit and thereby optimize the efficiency of hybrid development. For this, the genotypes to be evaluated are crossed with the same parents, called testers, aiming to assess the potential of these lines to transmit their desirable characteristics to the hybrids.

Theoretical and experimental studies have been reported about topcross efficiency in common maize (BARRIÈRE et al., 2010, GUEDES et al., 2011). Such studies have contributed to the decision on the choice of the testers, but they have not provided satisfactory answers to all questions.

Choosing an ideal tester is still a critical point in the breeding program (LI et al., 2007, LÜDERS et al., 2007). Testers may have a narrow (inbred lines, single hybrids) or broad genetic base (open pollinated varieties, three-way hybrids), be related or unrelated to the families to be tested, have high or low yield and high or low favorable allele frequencies. The choice depends upon the goals of the program. In tests applied to early inbreeding generations, broad genetic base testers should be preferred (HALLAUER; MIRANDA FILHO, 1995).

Popcorn is a food appreciated around the world. In Brazil, the cropped area lags behind the internal demand. National consumption has been kept at the expense of importing this grain. On the world scene, the United States is the largest producer and consumer of popcorn, whereas Brazil is the second largest producer, with an average annual production of 80000 tones (MOTERLE et al., 2012). A study by the Ministry of Agriculture, Livestock and Supply of Brazil (MAPA) showed that despite increasing demand, production is still limited in the country (ARNHOLD et al., 2009).

Despite the significant number of popcorn cultivars obtained over the past decade (RANGEL et al., 2008), economic factors have played an important role in reducing the popcorn crop expansion in Brazil. The valuation of Brazilian currency (real) against the dollar has favored the importation of popcorn, mainly from Argentina and the United States.
Research on popcorn testers is still incipient (BARRETO et al., 2012; MOTERLE et al., 2012; RODOVALHO et al., 2012). The main difficulty is finding efficient testers to discriminate families both for grain yield and popping expansion. These traits have different inheritance mechanisms and are usually negatively correlated, which slow the obtaining of new cultivars (BABU et al., 2006; MUNHOZ et al., 2009).

The present study aimed to evaluate the efficiency of three testers in discriminating $\mathrm{S}_{3}$ families derived from the popcorn hybrid IAC-125 as well as evaluating their general combining ability for grain yield and popping expansion, thereby contributing to the characterization and use of testers in topcrosses applied to popcorn breeding.

\section{MATERIAL AND METHODS}

\section{Genetic material}

One hundred and fourteen topcross hybrids developed by pollinating $38 \mathrm{~S}_{3}$ families with three testers were evaluated. These families derived from the IAC125 popcorn hybrid, which was obtained by crossing of a single-way hybrid with an American synthetic variety (SAWAZAKI, 1995). Testers were an inbred line $\mathrm{P}_{3.3}-\mathrm{S}_{7}$ generation sourced from popcorn population CMS-42, an open pollinated variety BRS Angela and the commercial three-way hybrid Jade.

\section{Field experiments and data collection}

Topcrosses between 38 popcorn families and three testers were obtained on the experimental farm of the Universidade Estadual de Maringá, Paraná, Brazil, during the 2010/2011 season. Plants of the endogamous families were pollinated by testers in a partial diallel mating design. Simultaneously, families were self-pollinated to obtain generation $\mathrm{S}_{4}$.

The topcross hybrids were evaluated in individual experiments for each tester (ELIAS et al., 2000) carried out in a randomized block design with three replications in two locations (Maringá and Sabáudia). Together with the topcrosses, two commercial popcorn controls (Jade and IAC-125) were added. Plots consisted of a single 5 $\mathrm{m}$ row of plants $0.90 \mathrm{~m}$ apart with 5 plants per meter as the final stand. Plant protection and fertilizer applications were performed as recommended agronomic practices.

Topcross hybrids, testers and controls were evaluated for grain yield and popping expansion. Grain yield values were expressed in $\mathrm{kg} \mathrm{ha}^{-1}$ and obtained by adjusting the grain mass to $13.50 \%$ moisture according to the number of plants per plot. For popping expansion, 
$30 \mathrm{~g}$ raw grains from each plot were expanded at $280{ }^{\circ} \mathrm{C}$ for 130 seconds in a standardized popcorn maker. This result was expressed in popcorn volume expanded per mass of raw grains $\left(\mathrm{mL} \mathrm{g}^{-1}\right)$.

\section{Statistical analyses}

Data analysis followed a linear model for randomized complete block design with combined analysis to locations. Estimates of the General Combining Ability (GCA) and Specific Combining Ability (SCA) were calculated from the means of crosses according to Griffing's model adapted by Geraldi and Miranda Filho (1988) to a partial diallel that presupposes the evaluation $p q$ hybrid combinations, with $p$ testers and $q \mathrm{~S}_{3}$ families. The effects of testers and families were considered to be fixed and random, respectively. The statistical model used was $Y_{i j}=\mu+g_{i}+g_{j}+s_{i j}+\varepsilon_{i j}$, where: $Y_{i j}$ : mean of hybrid combination between the $i^{\text {th }}$ tester and the $j^{\text {th }}$ family; $\mu$ : overall average; $g_{i}$ : general combining ability effect of the $i^{\text {th }}$ tester; $\mathrm{g}_{\mathrm{j}}$ : general combining ability effect of the $j^{\text {th }}$ family; $\mathrm{s}_{\mathrm{ij}}$ : specific combining ability effect of the $i^{\text {th }}$ tester and the $j^{\text {th }}$ family; $\varepsilon_{\mathrm{ij}:}$ error.

The genetic and phenotypic variances were estimated and efficiency of testers was evaluated through the Fasoulas index of differentiation (FASOULAS, 1983). This index corresponds to percentage of contrast between two means, which were significant in relation to all possible contrasts. The Spearman classificatory correlation was used to verify the degree of matching in the ratings of $\mathrm{S}_{3}$ families among testers (STEEL; TORRIE, 1980) and the significance was assessed by t-test. Analyses were performed with the software GENES (CRUZ, 2013).

\section{RESULTS AND DISCUSSION}

\section{Analysis of variance}

Processing of individual variance analysis in both locations revealed that the highest grain yield occurred in Sabáudia and the largest popping expansion was detected in Maringá (data not shown). According to the combined ANOVA analysis, highly significant effects were generally found for the interaction Treatments x Locations, indicating a differential behavior of genotypes by locations. However, the grain yield of Angela (an open pollinated variety) was similar in both locations (Table 1).

\section{Components of variance and heritability}

Regarding genetic parameters, the highest genotypic variances for grain yield both in Maringá [416,277 $\left.\left(\mathrm{kg} \mathrm{ha}^{-1}\right)^{2}\right]$ and Sabáudia [185,551( $\left.\left(\mathrm{kg} \mathrm{ha}^{-1}\right)^{2}\right]$ were observed in those topcrosses that shared Jade as a parental tester. This large variance is probably due to a larger genetic distance between Jade and the evaluated $\mathrm{S}_{3}$ families, suggesting that Jade is not genetically related to the mentioned families. Line $\mathrm{P}_{33}$ presents estimates of 383,805 [( $\left.\left.\mathrm{kg} \mathrm{ha}^{-1}\right)^{2}\right]$ in Maringá and $179,646\left[\left(\mathrm{~kg} \mathrm{ha}^{-1}\right)^{2}\right]$ in Sabáudia, which were relatively close to values found for Jade. A smaller estimate was found for Angela in Maringá [(172,784 $\left.\left(\mathrm{kg} \mathrm{ha}^{-1}\right)^{2}\right]$ and Sabáudia [162,095 $\left.\left(\mathrm{kg} \mathrm{ha}^{-1}\right)^{2}\right]$, therefore Angela seems to be related to the families with respect to those genes involved in the inheritance of grain yield.

A comparison of the genetic variation among the topcrosses derived from each evaluated tester was performed in relation to popping expansion. Topcrosses with Angela had the highest genetic variance for popping expansion in Maringá $\left[\left(8.61 \mathrm{~mL} \mathrm{~g}^{-1}\right)^{2}\right]$, followed by the ones with Jade $\left[\left(6.93 \mathrm{~mL} \mathrm{~g}^{-1}\right)^{2}\right.$ and $\mathrm{P}_{3.3}\left[\left(4.60 \mathrm{~mL} \mathrm{~g}^{-1}\right)^{2}\right]$. However, topcrosses with tester Jade had the highest genetic variance $\left.\left[19.85 \mathrm{~mL} \mathrm{~g}^{-1}\right)^{2}\right]$ for the same trait in Sabáudia, followed by topcrosses with Angela $\left[\left(9.10 \mathrm{~mL} \mathrm{~g}^{-1}\right)^{2}\right]$ and $\mathrm{P}_{3.3}\left[\left(4.06 \mathrm{~mL} \mathrm{~g}^{-1}\right)^{2}\right]$. Different results were obtained by Rodovalho et al. (2012), whose work showed larger genetic variances for popping expansion when a narrow genetic base inbred line was used as the tester.

The highest heritability estimate for grain yield ( $82 \%$ in Maringá and $75 \%$ in Sabáudia) was observed in topcrosses with line $\mathrm{P}_{3.3}$. As for popping expansion, topcrosses with Jade had the highest heritability among testers (82\% in Maringá and $83 \%$ in Sabáudia). Studies carried out by Barreto et al. (2012) and Rodovalho et al. (2012) also showed higher values for grain yield and popping expansion heritability when the tester was an inbred line.

\section{Diallel analysis}

According to the combined analysis of variance, there was statistical significance for the interactions effects of GCA Families $x$ Locations, showing the estimated GCA values ( $\hat{g}_{i}$ and $\hat{g}_{j}$ ) ranged between environments for grain yield and popping expansion (Table 2). Observing the GCA of testers, Angela had the highest $\hat{g}_{\mathrm{i}}$ predicted for grain yield, 174 using location average (data not shown). This result is consistent with the broad genetic base of the tester and the lack of genetic correlation between the Angela and $S_{3}$ families evaluated.

Topcrosses with Angela tester kept a consistent performance in different locations, with higher yield than topcrosses with other testers. On the other hand, the other testers had a negative GCA for grain yield in the average of locations, -143 for $\mathrm{P}_{3.3}$ and -31 for Jade, (data not shown). 
Table 1 - Combined variance analysis of the experiments carried out in Maringá and Sabáudia with three testers for grain yield $\left(\mathrm{GY}, \mathrm{kg} \mathrm{ha}^{-1}\right)$ and popping expansion (PE, $\left.\mathrm{mL} \mathrm{g}^{-1}\right)$, including coefficients of variation (CV\%), general mean and means of popcorn controls

\begin{tabular}{|c|c|c|c|c|c|c|c|}
\hline \multicolumn{8}{|c|}{ Mean Squares } \\
\hline \multirow{2}{*}{ SV } & \multirow{2}{*}{$\mathrm{DF}$} & \multicolumn{2}{|c|}{$\mathrm{P}_{3.3}$} & \multicolumn{2}{|c|}{ Angela } & \multicolumn{2}{|l|}{ Jade } \\
\hline & & $\mathrm{GY}$ & $\mathrm{PE}$ & $\mathrm{GY}$ & $\mathrm{PE}$ & $\mathrm{GY}$ & $\mathrm{PE}$ \\
\hline Blocks/Locations & 4 & $440,051.00$ & 9.88 & $262,310.00$ & $48,471.00$ & $480,659.00$ & 5.80 \\
\hline Treatment $(\mathrm{T})$ & 39 & $1,240,722.00^{\mathrm{ns}}$ & $21.70^{\mathrm{ns}}$ & $1234,613.00 * *$ & $39.16^{\mathrm{ns}}$ & $1485,227.00^{\mathrm{ns}}$ & $54.58^{\mathrm{ns}}$ \\
\hline Locations (L) & 1 & $888,653.00^{\mathrm{ns}}$ & $473,316.00^{\mathrm{ns}}$ & $174,043.00^{\mathrm{ns}}$ & $104,491.00^{\mathrm{ns}}$ & $1,623,450.00^{\mathrm{ns}}$ & $48.57^{\mathrm{ns}}$ \\
\hline $\mathrm{T} \times \mathrm{L}$ & 39 & $877,485 * *$ & $15.99 * *$ & $552,270.00^{\mathrm{ns}}$ & $25.49 * *$ & $1,010,140.00 * *$ & $42.26 * *$ \\
\hline Error & 156 & $213,926.00$ & 5.86 & $391,121.00$ & 5.76 & $344,941.00$ & 8.26 \\
\hline Jade Average & & $2,821.00$ & 28.78 & $2,968.00$ & 28.89 & $3,146.00$ & 27.89 \\
\hline IAC-125 Average & & $2,957.00$ & 31.34 & $2,890.00$ & 31.67 & $3,285.00$ & 28.78 \\
\hline General mean & & $3,354.00$ & 29.21 & $3,658.00$ & 27.03 & $3,477.00$ & 27.14 \\
\hline $\mathrm{CV} \%$ & & 13.79 & 8.29 & 17.10 & 8.88 & 16.89 & 10.59 \\
\hline
\end{tabular}

**, *, F test significant at probability $1 \%$ and $5 \%$, respectively

Table 2 - Combined analysis of variance of the partial diallel mating design for grain yield $\left(\mathrm{GY}, \mathrm{kg} \mathrm{ha}^{-1}\right)$ and popping expansion $\left(\mathrm{PE}, \mathrm{mL} \mathrm{g}^{-1}\right)$

\begin{tabular}{lrcc}
\hline \multirow{2}{*}{ Source of variation $\dagger$} & \multicolumn{2}{c}{ Mean squares } \\
\cline { 2 - 4 } & DF & GY & PE \\
\hline Treatments & 113 & $1,379,422.94^{* *}$ & $34.52^{* *}$ \\
GCA Testers & 2 & $5,926,151.22^{*}$ & $367.43^{\mathrm{ns}}$ \\
GCA Families & 37 & $2,371,567.99^{* *}$ & $60.16^{\mathrm{ns}}$ \\
SCA & 74 & $760,465.87^{\mathrm{ns}}$ & $27.98^{\mathrm{ns}}$ \\
Locations & 1 & $1,153,989.80^{\mathrm{ns}}$ & $416.85^{* *}$ \\
Treatments x Locations & 113 & $767,455.70^{* *}$ & $28.34^{* *}$ \\
GCA Testers x Locations & 2 & $258,423.41^{\mathrm{ns}}$ & $44.48^{* *}$ \\
GCA Families x Locations & 37 & $967,022.26^{* *}$ & $34.85^{* *}$ \\
SCA x Locations & 74 & $681,430.06^{* *}$ & $24.65^{* *}$ \\
Error & 468 & $316,663.00$ & 6.62 \\
General mean & & $3,522.00$ & 27.70 \\
\hline
\end{tabular}

$\lceil$ General combining ability (GCA), Specific combining ability (SCA), **, *, F test significant at probability $1 \%$ and $5 \%$, respectively

Studying $\mathrm{S}_{2}$ popcorn families sourced from IAC125, also crossed with Angela as tester, Barreto et al. (2012) had the highest value of the $\mathrm{g}_{\mathrm{i}}$ estimate among the testers for Angela. This outcome could be linked to a higher quality of gametes in Angela, with high frequency of favorable alleles, built over several selection cycles in which this open-pollination variety was developed (RANGEL et al., 2011). Significant interaction between SCA and locations was detected, but not significant single effects of SCA were found, showed that SCA has to be considered based on its performance at each location.
Regarding the behavior of the testers for the popping expansion, the values of $\hat{g}_{i}$ indicated the superiority of $\mathrm{P}_{3.3}$ line in both locations (1.96 and 0.96 in Maringá and Sabáudia), other than the negative coefficients observed for other testers (-1.01 and -0.66 for Angela, -0.95 and -0.29 for Jade). The genotypic variance of the topcrosses obtained with tester $\mathrm{P}_{3.3}$ was smaller than the corresponding variances associated with the other testers for popping expansion, regardless of the location where the evaluation was performed. This tester can be genetically related to families and 
share alleles with popping expansion, a trait where additive genetic control prevails. Similarly, other authors found a higher $\hat{\mathrm{g}}_{\mathrm{i}}$ to popcorn quality when the tester was related to the evaluated families, often from the same genetic material of the families in the test (BARRETO et al., 2012; RODOVALHO et al., 2012).

The highest $\hat{\mathrm{g}}_{\mathrm{j}}$ values to grain yield in Maringá were detected in families $\mathrm{F}_{8}, \mathrm{~F}_{9}, \mathrm{~F}_{14}, \mathrm{~F}_{15}, \mathrm{~F}_{16}, \mathrm{~F}_{17}, \mathrm{~F}_{20 \text {, }}$ $\mathrm{F}_{22}, \mathrm{~F}_{23}$ and $\mathrm{F}_{31}$, ranging from 325 to 1178 . In Sabáudia, families $\mathrm{F}_{6}, \mathrm{~F}_{8}, \mathrm{~F}_{9}, \mathrm{~F}_{10}, \mathrm{~F}_{12}, \mathrm{~F}_{16}, \mathrm{~F}_{19}, \mathrm{~F}_{22}, \mathrm{~F}_{23}, \mathrm{~F}_{31}$ and $\mathrm{F}_{33}$ had high coefficients for general combining ability, ranging from 177 to 668 (Table 3). Despite the statistical significance of the interaction for the GCA- Families $\mathrm{x}$ Locations, it should be noted that families $\mathrm{F}_{8}, \mathrm{~F}_{9}$, $\mathrm{F}_{16}, \mathrm{~F}_{22}, \mathrm{~F}_{23}$, and $\mathrm{F}_{31}$ provide positive and satisfactory $\hat{\mathrm{g}}_{\mathrm{j}}$ estimates at both sites, helping to increase the grain yield average on $658 \mathrm{~kg} \mathrm{ha}^{-1}$ in Maringá and $428 \mathrm{~kg} \mathrm{ha}^{-1}$ in Sabáudia.
About the popping expansion, families $\mathrm{F}_{1}, \mathrm{~F}_{4} \mathrm{~F}_{7}$, $\mathrm{F}_{10}, \mathrm{~F}_{13}, \mathrm{~F}_{18}, \mathrm{~F}_{21}, \mathrm{~F}_{22} \mathrm{~F}_{24}, \mathrm{~F}_{30}, \mathrm{~F}_{34}, \mathrm{~F}_{35}$ and $\mathrm{F}_{36}$ had the highest values of $\mathrm{g}_{\mathrm{j}}$ in Maringá, ranging from 3.67 to 1.30. In Sabáudia, families $\mathrm{F}_{4}, \mathrm{~F}_{5}, \mathrm{~F}_{6}, \mathrm{~F}_{7}, \mathrm{~F}_{12}, \mathrm{~F}_{13}, \mathrm{~F}_{16}, \mathrm{~F}_{21}, \mathrm{~F}_{24}, \mathrm{~F}_{28}$, $\mathrm{F}_{31}, \mathrm{~F}_{32}, \mathrm{~F}_{34}$ and $\mathrm{F}_{36}$ had the best performance, ranging from 4.41 to 0.93 . Positive and consistent estimates of $\hat{g}_{j}$ for both locations were obtained by families $\mathrm{F}_{4}, \mathrm{~F}_{7}, \mathrm{~F}_{13}, \mathrm{~F}_{21}, \mathrm{~F}_{24}, \mathrm{~F}_{34}$ and $\mathrm{F}_{36}$. The contribution from these families increased the general mean for popping expansion to $2.56 \mathrm{~mL} \mathrm{~g}^{-1}$ in Maringá and $2.93 \mathrm{~mL} \mathrm{~g}^{-1}$ in Sabáudia, considering those crossings where such families participated as genitors. However, except for popping expansion in Maringá, only families $\mathrm{F}_{16}$ and $\mathrm{F}_{31}$ can be considered as promising genotypes following the criteria proposed by Singh and Chaudhary (2010). According to them, the most promising families are the ones that show significant and positive values of $\hat{g}_{i}$, especially those whose $\hat{g}_{i}$ exceeds at least twice the estimated standard deviation. In Table 4, the ranking of the four promising families in crossings with every tester is presented for GCA, grain yield and popping expansion.

Table 3 - Estimates of GCA effects $\left(\hat{g}_{j}\right)$ associated with $\mathrm{S}_{3}$ families for grain yield $\left(\mathrm{GY}, \mathrm{kg} \mathrm{ha}^{-1}\right)$ and popping expansion $\left(\mathrm{PE}, \mathrm{mL} \mathrm{g}{ }^{-1}\right)$ in Maringá and Sabáudia

\begin{tabular}{lcccc}
\hline & \multicolumn{5}{c}{ Estimates of GCA effects $\left(\hat{\mathrm{g}}_{\mathrm{j}}\right)$} \\
\cline { 2 - 5 } $\mathrm{S}_{3}$ families & \multicolumn{5}{c}{ GY } & Maringá & Sabáudia \\
\cline { 2 - 5 } & Maringá & Sabáudia & 2.63 & -0.10 \\
\hline $\mathrm{F}_{1}$ & -25 & -661 & -1.07 & -2.55 \\
$\mathrm{~F}_{2}$ & -841 & -46 & 0.26 & -0.62 \\
$\mathrm{~F}_{3}$ & -113 & 53 & 1.52 & 2.56 \\
$\mathrm{~F}_{4}$ & 134 & 173 & 0.04 & 1.08 \\
$\mathrm{~F}_{5}$ & 38 & 90 & -0.85 & 2.34 \\
$\mathrm{~F}_{6}$ & -55 & 177 & 2.33 & 0.93 \\
$\mathrm{~F}_{7}$ & 254 & 47 & -6.48 & -1.36 \\
$\mathrm{~F}_{8}$ & 811 & 585 & -1.37 & -0.92 \\
$\mathrm{~F}_{9}$ & 1,178 & 243 & 1.81 & -2.40 \\
$\mathrm{~F}_{10}$ & -55 & 668 & 0.48 & 0.63 \\
$\mathrm{~F}_{11}$ & -197 & -30 & -3.74 & 1.75 \\
$\mathrm{~F}_{12}$ & -187 & 429 & 1.67 & 3.60 \\
$\mathrm{~F}_{13}$ & -188 & -478 & 0.93 & -1.44 \\
$\mathrm{~F}_{14}$ & 325 & -205 & -0.78 & -2.18 \\
$\mathrm{~F}_{15}$ & 572 & -75 & 0.11 & 2.08 \\
$\mathrm{~F}_{16}$ & 489 & 398 & 0.11 & -0.40 \\
$\mathrm{~F}_{17}$ & 411 & -155 & 2.48 & -1.59 \\
$\mathrm{~F}_{18}$ & -229 & -745 & -3.89 & 0.19 \\
$\mathrm{~F}_{19}$ & -422 & 310 & -2.55 & -1.96 \\
$\mathrm{~F}_{20}$ & 839 & -113 & &
\end{tabular}


Continued Table 3

\begin{tabular}{lcccc}
\hline $\mathrm{F}_{21}$ & -651 & -253 & 3.67 & 3.30 \\
$\mathrm{~F}_{22}$ & 618 & 383 & 1.3 & -0.77 \\
$\mathrm{~F}_{23}$ & 453 & 322 & $-2,55$ & -0.62 \\
$\mathrm{~F}_{24}$ & -295 & -196 & 2.78 & 1.97 \\
$\mathrm{~F}_{25}$ & -78 & 19 & 0.34 & -1.96 \\
$\mathrm{~F}_{26}$ & 254 & 55 & -1.15 & 0.49 \\
$\mathrm{~F}_{27}$ & 297 & -442 & -0.04 & -4.33 \\
$\mathrm{~F}_{28}$ & 2 & -19 & -4.48 & 1.00 \\
$\mathrm{~F}_{29}$ & 145 & 82 & -1.59 & -2.92 \\
$\mathrm{~F}_{30}$ & -313 & 79 & 2.11 & -4.48 \\
$\mathrm{~F}_{31}$ & 396 & 638 & 0.56 & 1.6 \\
$\mathrm{~F}_{32}$ & -6 & -92 & 0.11 & 2.97 \\
$\mathrm{~F}_{33}$ & -105 & 417 & -1.14 & -3.88 \\
$\mathrm{~F}_{34}$ & -961 & -422 & 3.59 & 4.41 \\
$\mathrm{~F}_{35}$ & -740 & -536 & 2.85 & 0.26 \\
$\mathrm{~F}_{36}$ & -610 & -93 & 2.34 & 3.75 \\
$\mathrm{~F}_{37}$ & -969 & -574 & -1.37 & -0.03 \\
$\mathrm{~F}_{38}$ & -32 & -0.92 & -0.40 \\
$\mathrm{SD}\left(\hat{\mathrm{g}}_{\mathrm{i}}\right)$ & 182 & 182 & 0.76 & 0.92 \\
$\mathrm{SD}\left(\hat{\mathrm{g}}_{\mathrm{i}}-\hat{\mathrm{g}}_{\mathrm{i}}\right)$ & 187 & 261 & 1.09 & 1.32 \\
\hline
\end{tabular}

Table 4 - Ranking of the families with the highest effects of GCA for grain yield (GY) and popping expansion (PE) as a result of the topcrosses evaluated in two locations

\begin{tabular}{|c|c|c|c|c|c|c|c|c|}
\hline \multirow{2}{*}{$\mathrm{S}_{3}$ families } & \multicolumn{2}{|c|}{ GCA } & \multicolumn{2}{|c|}{$\mathrm{P}_{33}$} & \multicolumn{2}{|c|}{ Angela } & \multicolumn{2}{|c|}{ Jade } \\
\hline & GY & $\mathrm{PE}$ & GY & $\mathrm{PE}$ & GY & $\mathrm{PE}$ & GY & $\mathrm{PE}$ \\
\hline \multicolumn{9}{|c|}{ Maringá } \\
\hline $\mathrm{F}_{4}$ & $15^{\circ}$ & $3^{\circ}$ & $14^{\circ}$ & $27^{\circ}$ & $30^{\circ}$ & $10^{\circ}$ & $11^{\circ}$ & $9^{\circ}$ \\
\hline $\mathrm{F}_{7}$ & $13^{\circ}$ & $1^{\circ}$ & $18^{\circ}$ & $14^{\circ}$ & $19^{\circ}$ & $18^{\circ}$ & $6^{\circ}$ & $1^{\circ}$ \\
\hline $\mathrm{F}_{16}$ & $6^{\circ}$ & $20^{\circ}$ & $5^{\circ}$ & $17^{\circ}$ & $5^{\circ}$ & $24^{\circ}$ & $17^{\circ}$ & $23^{\circ}$ \\
\hline $\mathrm{F}_{31}$ & $4^{\circ}$ & $15^{\circ}$ & $10^{\circ}$ & $3^{\circ}$ & $9^{o}$ & $23^{\circ}$ & $9^{\circ}$ & $32^{\circ}$ \\
\hline \multicolumn{9}{|c|}{ Sabáudia } \\
\hline $\mathrm{F}_{4}$ & $12^{\circ}$ & $3^{\circ}$ & $2^{\circ}$ & $26^{\circ}$ & $38^{\circ}$ & $15^{\circ}$ & $13^{\circ}$ & $4^{\circ}$ \\
\hline $\mathrm{F}_{7}$ & $18^{\circ}$ & $10^{\circ}$ & $16^{\circ}$ & $4^{\circ}$ & $30^{\circ}$ & $13^{\circ}$ & $8^{\circ}$ & $33^{\circ}$ \\
\hline$F_{16}$ & $6^{\circ}$ & $8^{\circ}$ & $18^{\circ}$ & $18^{\circ}$ & $6^{\circ}$ & $20^{\circ}$ & $9^{\circ}$ & $13^{\circ}$ \\
\hline $\mathrm{F}_{31}$ & $7^{\circ}$ & $11^{\circ}$ & $7^{\circ}$ & $15^{\circ}$ & $3^{\circ}$ & $22^{\circ}$ & $3^{\circ}$ & $11^{\circ}$ \\
\hline
\end{tabular}

Spearman classificatory correlation

Spearman correlation analysis among rankings by testers indicated major coincidences for grain yield in Maringá. Correlations of $0.42^{*}$ between Angela and $\mathrm{P}_{3,3}$, $0.49^{*}$ between Jade and $\mathrm{P}_{33}$ and $0.38^{*}$ between Jade and Angela were observed ( $(\mathrm{p}<0.05)$. In Sabáudia, Angela and
$\mathrm{P}_{3.3}$ were essentially uncorrelated because the correlation coefficient between their rankings was not significant at $5 \%$ level $\left(-0.02^{\mathrm{ns}}\right)$. The other coefficients observed in Sabáudia ranged from $0.25^{*}$ (between $\mathrm{P}_{33}$ and Jade) to 0.34* (between Angela and Jade). Whatever the genetic 
basis of the testers employed, the correlations between the performance of families in crossings with several testers are probably smaller than 0.50 for traits controlled by a large number of dominant genes, such as grain yield (HUANG et al., 2013; SMITH, 1986).

Correlations were higher for popping expansion in Maringá. Correlations of $0.44^{*}$ between Angela and $\mathrm{P}_{3.3}, 0.48^{*}$ between Jade and $\mathrm{P}_{3.3}$ and $0.61^{*}$ between Jade and Angela were observed. In Sabáudia the correlation coefficients for popping expansion were smaller: $-0.01^{\mathrm{ns}}$ between Jade and Angela, $0.06^{\mathrm{ns}}$ between Jade and $\mathrm{P}_{3.3}$ and $0.15^{\text {ns }}$ between $\mathrm{P}_{3.3}$ and Angela.

\section{Fasoulas index of differentiation and choice of the tester}

Fasoulas index of differentiation (Fasoulas, 1983) was applied to estimate the efficiency of testers. This index $(D)$ corresponds to the percentage of significant contrast between two means in relation to all possible contrasts. The inbred line $\mathrm{P}_{3,3}$ has the highest $D$ value for grain yield, sorting $29.02 \%$ and $23.19 \%$ of families in Maringá and Sabáudia, respectively. For popping expansion, Jade showed the highest $D$ values both in Maringá and Sabáudia $33.00 \%$ and 36.84\%, respectively). It should be noted that the index of Jade was also high for grain yield $(27.31 \%$ and $12.38 \%$ in Maringá in Sabáudia, respectively). Therefore, for its good performance in evaluating both traits simultaneously, Jade was considered the best tester for this set of families derived from the popcorn hybrid IAC- 125 .

The tester Angela did not perform well in sorting for grain yield $(6.69 \%$ and $12.38 \%$ in Maringá and Sabáudia), but it was an excellent tester for popping expansion $(22.19 \%$ and $33.15 \%$ in Maringá and Sabáudia).

With respect to the evaluated families, $\mathrm{F}_{4}, \mathrm{~F}_{7}, \mathrm{~F}_{16}$ and $\mathrm{F}_{31}$ presented a great CGA for both traits, including a great performance regardless of location. These seem to be the most promising families among the $\mathrm{S}_{3}$ families evaluated.

\section{CONCLUSIONS}

1. Jade was considered the best tester because of its good performance in evaluating popping expansion and grain yield simultaneously;

2. Angela was an excellent tester when testing exclusively for popping expansion;

3. Families $\mathrm{F}_{4}, \mathrm{~F}_{7}, \mathrm{~F}_{16}$ and $\mathrm{F}_{31}$ were the most promising families among the $\mathrm{S}_{3}$ families evaluated.

\section{REFERENCES}

ARNHOLD, E. et al. Produtividade de híbridos de milho em região de fronteira agrícola no nordeste do Maranhão. Revista Brasileira de Ciência Agronômica, v. 5, n. 4, p. 468-47, 2010.

BABU, R. et al. MAPPING QTLs for popping ability in a popcorn x flint corn cross. Theoretical Applied Genetics, v. 112, n. 7, p. 1392-1399, 2006.

BARRETO, R. R. et al. Avaliação da capacidade de combinação de famílias $\mathrm{S}_{2}$ de milho-pipoca por meio de diferentes testadores. Semina: Ciências Agrárias, v. 33, n. 3, p. 873-890, 2012.

BARRIÈRE, Y. et al. QTL for yield, earliness, and cell wall quality traits in topcross experiments of the F838 $\times$ F286 early maize RIL progeny. Crop Science, v. 50, n. 5, p. 1761-1772, 2010.

CRUZ, C. D. GENES: A software package for analysis in experimental statistics and quantitative genetics. Acta Scientiarum Agronomy, v. 35, n. 3, p. 271-276, 2013.

CRUZ, C. D.; REGAZZI, A. J.; CARNEIRO, P. C. S. Análise dialélica. In: CRUZ, C. D.; REGAZZI, A. J.; CARNEIRO. P. C. $\mathrm{S}$. Modelos biométricos aplicados ao melhoramento genético I, 4. ed. Viçosa: Editora UFV, 2012. p. 321-330. Cap. 7.

ELIAS, H. T.; CARVALHO, S. P.; ANDRÉ, C. G. M. Comparação de testadores na avaliação de famílias $S_{2}$ de milho. Pesquisa Agropecuária Brasileira, v. 35, n. 6, p. 1135-1142, 2000.

FASOULAS, A. C. Rating cultivars and trials in applied plant breeding. Euphytica, v. 32, n. 3, p. 939-943, 1983.

GERALDI, I. O.; MIRANDA FILHO, J. B. Adapted models forth analysis of combining ability of varieties in partial diallel crosses. Brazilian Journal of Genetics, v. 2, p. 419-430, 1988.

GUEDES, F. L. et al. Evaluation of maize top crosses under two nitrogen levels. Ciência e Agrotecnologia, v. 35, n. 6, p. 11151121,2011

HALLAUER, A. R.; MIRANDA FILHO, J. B. Quantitative genetics in maize breeding. 2.ed. Ames: Iowa State University, 1995. $468 \mathrm{p}$.

HUANG, J. et al. General combining ability of most yield-related traits had a genetic basis different from their corresponding traits per se in a set of maize introgression lines. Genetica, v. 141, p. 453-46, 2013.

JENKINS, M. T. The effect of inbreding and of selection within inbred lines of maize upon hybrids made after successive generations of selfing. Iowa State College Journal Science, v. 9, p. 429-450, 1935

LI, M. S. et al. Comparisons of four testers in evaluating 27 CIMMYT and Chinese maize populations. Maydica, v. 52, p. 173-179, 2007.

LÜDERS, R. R.; et al. Combining ability of maize lines in top crosses with narrow genetic base testers, Revista Brasileira de Milho e Sorgo, v. 6, n. 2, p. 186-198, 2007. 
MOTERLE, L. M. et al. Combining ability of popcorn lines for seed quality and agronomic traits. Euphytica, v. 185, n. 3, p. 337-347, 2012.

MUNHOZ, R. E. F. et al. Genetic distances between popcorn populations based on molecular markers and correlations with heterosis estimates made by diallel analysis of hybrids. Genetics and Molecular Research, v. 8, n. 3, p. 951-962, 2009.

PINNISCH, R. et al. Evaluation of maize (Zea mays L) inbred lines for yield component traits and kernel morphology. Maydica, v. 57, p. $1-5,2012$.

RANGEL, R. M. et al. Análise biométrica de ganhos por seleção em população de milho pipoca de quinto ciclo de seleção recorrente. Revista Ciência Agronômica, v. 42, n. 2, p. 473481,2011 .

RANGEL, R. M. et al. Genetic parameters in parents and hybrids of circulant diallel in popcorn. Genetics and Molecular Research, v. 7, n. 4, p. 1020-1030, 2008.
RODOVAlHO, M. A. et al. Comparação de testadores em famílias $\mathrm{S}_{2}$ obtidas do híbrido simples de milho-pipoca IAC112. Bioscience Journal, v. 28, n. 2, p. 145-154, 2012.

SAWAZAKI, E. Melhoramento de milho pipoca. Campinas: IAC, 199521 p. (Documentos IAC, 53).

SINGH, R. K.; CHAUDHARY, B. D. Biometrical methods in quantitative genetic analysis. Ed. rev. New Delli: Kalayani Publishers, 2010. 318 p.

SMITH, O. S. Covariance between line per se and testcross performance. Crop Science, v. 26, n. 3, p. 540-543, 1986.

SPRAGUE, G. F. Early testing of inbred lines of corn. American Society of Agronomy, v. 38, p. 108-117, 1946.

STEEL, R. G. D.; TORRIE, J. H. Principles and procedures of statistics: A biometrical approach. 2. ed. New York: McGraw-Hill, 1980. 633 p. 